\title{
Qualitative identification of the active principles in Citrullus colocynthis and evaluation of its teratogenic effects in albino rats
}

\author{
Amer Abdalla Elgerwi ${ }^{1}$ *, Zuhira Benzekri ${ }^{2}$, Abdelrazzag El-Magdoub ${ }^{1}$, \\ Abubakr El-Mahmoudy ${ }^{3}$
}

${ }^{1}$ Department of Pharmacology and Forensic Medicine and Toxicology, Faculty of Veterinary Medicine, University of Tripoli, 13662 Tripoli, Libya

${ }^{2}$ Menchya Clinic, Ministry of Health, 5688 Tripoli, Libya ${ }^{3}$ Department of Pharmacology, Benha University Faculty of Veterinary Medicine, 13736 Moshtohor, Egypt

Received: 26 May 2013

Accepted: 13 June 2013

*Correspondence to:

Dr. Amer Abdalla Elgerwi,

Email: amer.elgerwi@gmail.com

(C) 2013 Elgerwi AA et al. This is an open-access article distributed under the terms of the Creative Commons Attribution License, which permits unrestricted use, distribution, and reproduction in any medium, provided the original work is properly cited.

\begin{abstract}
Background: This study was designed to identify the active contents of Citrullus colocynthis plant and to examine their teratogenicity in rats. The fruit pulp of the poisonous plant was collected randomly from Suq-Alkhamis district, Tripoli, Libya.

Methods: The glucoside colocynthin was isolated by lead acetate method while the alkaloids and saponins were isolated by maceration method. These active principles were then identified by chemical tests, color reactions and thin layer chromatography. Possible teratogenic effects of the fruit pulp extract was investigated by its administration to twelve pregnant rats on the $7^{\text {th }}$ day of gestation at a dose of $40.6 \mathrm{mg} / \mathrm{kg}$ body weight that is equivalent to one fourth of the $\mathrm{LD}_{50}$ of the extract.

Results: Gross anatomical observation on the $20^{\text {th }}$ day of gestation revealed a high percentage of resorbed fetuses, smaller size and weight fetuses as well as absence of coccygeal vertebrae, metacarpal and metatarsal bones, and carpal and tarsal bones.

Conclusions: It could be concluded that the extract of fruit pulp of Citrullus colocynthis, obtained from Libya, contain glucosidal as well as other principles that may cause teratogenic effects if given during at the early stage of pregnancy.
\end{abstract}

Keywords: Citrullus colocynthis, Glucosides, Alkaloids, Saponins, Fetuses, Malformations

\section{INTRODUCTION}

Intoxication caused by poisonous plants is of an alimentary character. Animals are exposed to this danger both while grazing and in the Stable. Although there has been considerable progress in the livestock feeding, the presence of poisonous plants in the feed rations still remains an important factor limiting or reducing the overall efficiency of farm animals breeding. ${ }^{1}$ Acute or chronic poisoning by toxic plants constitutes an important obstacle in animal production and thereby causing substantial harm to the national economy. Many species of tropical poisonous plants grow abundantly in Libya; among these is Cucurbitaceae family. ${ }^{2}$ The family is composed of $90-100$ genera and 850 species. The active substances present in the plant include a number of several toxic active components as alkaloids, glucosides, saponins and tannins depending, to a great extent, on ecological factors and genetic basis. ${ }^{3}$

Various studies on toxic and/or medicinal effects of Citrullus colocynthis have been reported, yet, a few ones have been related to its teratogenic effect and, moreover, none was in Libya. Along the toxic studies, Citrullus colocynthis has been found to have toxic effects in goats, ${ }^{4,5}$ sheep, ${ }^{6,7}$ calves, ${ }^{3}$ chicks ${ }^{8}$ and rats. ${ }^{9}$ 
On the other hand, medicinal effects have been recorded for Citrullus colocynthis, including, antioxidant, ${ }^{10}$ antimicrobial, ${ }^{11}$ anti-inflammatory, ${ }_{14}^{11}$ antihistaminic, ${ }^{12}$ antiparasitic, ${ }^{13}$ antihyperlipidemic, ${ }^{14}$ anti-ulcer ${ }^{15}$ and antidiabetic $^{16}$ effects.

Phytochemical investigation of the active ingredients of Citrullus colocynthis fruits growing in Libya has been a subject of interest particularly because of their toxicological effect on animals and wide spread in Libyan environment. Therefore, the aim of the present study was to determine the active principles contained in the pulp of the Citrullus colocynthis plant growing in Libya; and to evaluate its teratogenicity.

\section{METHODS}

1. The plant: Citrullus colocynthis is a perennial, monoecious, spreading, roughly hispid creeping herb with simple tendrils and pinnatisect leaves. Flowers are yellow, ovary sparsely hispid and fruits are globose, yellow and smooth with a bitter taste. The plant is flowering almost throughout the year (Figure 1) ${ }^{2}$. The plant is distributed in different localities in Libya; but the plant used in this study was collected from Suq-Alkhamis district in Tripoli.

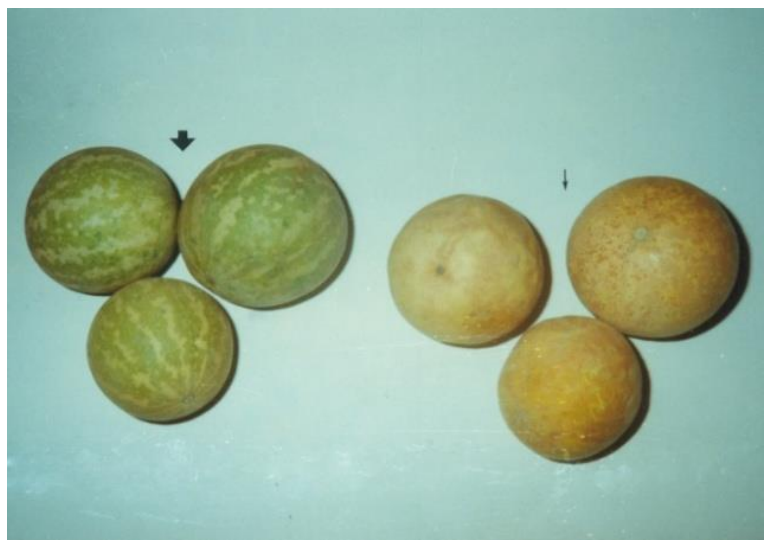

Figure 1: The fruit pulp of Citrullus colocynthis poisonous plant growing in Libya

2. Extraction of the active ingredients: Extraction of glucosides was carried out according to ${ }^{17}$ where the minced fruit pulp was covered with an equal weight of both $96 \%$ alcohol and saturated basic lead acetate solution. Under these conditions all the hydrolytic enzymes in the mixture were destroyed. Filtration gave a clear liquid from which the excess of lead acetate was removed after precipitation with a saturated aqueous solution of potassium dihydrogen phosphate. Chloroform extraction removed the bitter principles completely from the aqueous phase. Whitish foams were obtained as residues of the evaporation of the chloroform extract and used only for detection of glucosides.

The extraction of the alkaloids, saponins and tannins from the fruit pulp was carried out by maceration. The minced fruit was covered with double volume of distilled water for $24 \mathrm{hrs}$. and then filtrated, purified and dried on drying cabinet at $36{ }^{\circ} \mathrm{C}$ for 7 days. ${ }^{18}$

\section{Qualitative identification of the active ingredients}

3.1.1. Chemical tests: Molisch's, Baljet's, Fehling's and Benedict's tests were used for detection of glucosides while Mayer's, Wagner's, Dragendorff's, Hager's and tannic acid tests were used for detection of alkaloids; foam, mercurous chloride and silver nitrate tests were used for identification of saponins; and ferric chloride and tannic acid tests were used for detection of tannins.

Molisch's reagent test: The reagent composed of $1 \%$ alcoholic alpha-napthol. The test was carried out by adding a few drops of $1 \%$ alcoholic alpha-naphthol to5 $\mathrm{ml}$ of the plant extract and then 1 to 3 drops of concentrated sulphuric acid onto the wall of the tube.

Baljet's reagent test:The reagent composed of $95 \mathrm{ml}$ of $1 \%$ of picric acid solution in ethanol and $5 \mathrm{ml}$ of $10 \%$ alcoholic potassium hydroxide solution. The solution was filtrated and the filtrate was used as the reagent. To a small portion of the ethanolic extract an equal volume of theBaljet's reagent was added.

Fehling's test: Equal amounts of Fehling's solution and aqueous extract of the minced fruit pulp were mixed and heated in a boiling water bath for 10 minutes.

Benedict's test: Ten drops of the aqueous extract of the minced fruit pulp was added to $5 \mathrm{ml}$ of Benedict's reagent in a test tube and heated in a boiling water bath for 10 minutes.

Mayer's test: Ten grams of the minced extract were boiled with $50 \mathrm{ml}$ of $1 \%$ acidulated water and filtrated after cooling. Thirteen and half grams of mercuric chloride were dissolved in one liter of $5 \%$ aqueous solution of potassium iodide to prepare Mayer's reagent. The test was performed by adding a few drops of the freshly prepared Mayer's reagent to $5 \mathrm{ml}$ of acidulated plant filtrate.

Wagner's test: Fifty five grams of iodine dissolved in $10 \%$ solution of potassium iodide in water. A few drops of the freshly prepared Wagner's reagent were added to 5 $\mathrm{ml}$ of the acidulated filtrate of fruit plant extract.

Dragendorff's test: Two grams of bismuth sub-nitrate in $25 \mathrm{ml}$ acetic acid along with 40 grams of potassium iodide diluted to $100 \mathrm{ml}$ of water.

Hager's test: A cold saturated aqueous solution of picric acid was added to equal amount of the acidulated filtrate that was prepared as mentioned above.

Tannic acid test: Five grams of tannic acid were diluted with $95 \mathrm{ml}$ distilled water, the test was carried out by 
mixing $3 \mathrm{ml}$ of the filtrated extract with $2 \mathrm{ml}$ of the diluted tannic acid.

Foam test: The extract $(50 \mathrm{mg})$ was diluted with distilled water and made up to $20 \mathrm{ml}$. The suspension was shaken in a graduated cylinder for $15 \mathrm{~min}$. A long lasting two $\mathrm{cm}$ layer of foam indicated the presence of saponins.

Mirror test: Equal amounts of ammoniated silver nitrate (1\%) and the aqueous filtrate are mixed and boiled for 10 min in water bath.

Mercurous chloride test: Two ml of mercurous chloride (1\%) solution was added to $5 \mathrm{ml}$ of aqueous filtrate.

Ferric chloride test: The extract $(50 \mathrm{mg})$ was dissolved in $5 \mathrm{ml}$ of distilled water. To this, a few drops of neutral $5 \%$ ferric chloride solution were added. A dark green colour indicated the presence of tannin or phenolic compounds.

3.1.2. Color reaction tests: The color reactions were carried out according to the method described by. ${ }^{19}$ The reagents used were: Marquis (sulphuric formaldehyde reagent; two drops of formaldehyde solution were mixed with $1 \mathrm{ml}$ of sulphuric acid),alizarin red (1\% Alizarin in $50 \%$ ethanol), bromo-cresol green ( $1 \%$ bromocresol in ethanol), Frohde (a micro-drop of $0.5 \%$ aqueous ammonium molybdate solution is added to a micro-drop of the test solution, evaporated, and then moistened with sulphuric acid and the color is noticed), Vitali (a microdrop of the test solution is allowed to dry and a microdrop of a fuming nitric acid is added; the residue is then moistened with freshly prepared ethanolic potassium hydroxide and the color is noticed), Libermann (one $\mathrm{g}$ of potassium nitrate in $10 \mathrm{ml}$ of sulphuric acid), mercurous nitrate (a saturated solution of mercurous nitrate in water), Beam's (5 $\mathrm{g}$ of potassium hydroxide is dissolved in sufficient ethanol to $100 \mathrm{ml}$ ), ferric chloride (five percent solution of ferric chloride; $5 \mathrm{~g}$ of ferric chloride dissolved in $95 \mathrm{ml}$ distilled water) and finally, diluted acetic acid (five percent aqueous acetic acid; 5 volumes of acetic acid diluted to 100 volumes with distilled water).

3.1.3. Thin layer Chromatography: Chromatographic technique is one of the most outstanding methods for the purification, separation, detection and identification in toxicological studies. The separation and identification of the active ingredients of the poisonous plant Citrullus colocynthis was carried out chromatographically according to ${ }^{20 \& 21}$. Chromatography (color writing) is used for the separation of small amounts of closely related substances by continuous redistribution between two phases, stationary and mobile phases. ${ }^{22}$ The idea is based on the selective absorption of the components from a solution on the active surface of a finely divided solid. Closely related substances exhibit different abilities to adsorption, so that separations which are impractical by ordinary chemical methods may be easily done by this means. A solution, of the substances to be separated in a suitable solvent is moved post the stationary phase which has a tendency to adsorb different substances in varying degrees and rates. ${ }^{20}$ When the plates are being developed, the solvent moving through the thin layer tends to draw substances being analyzed along with it and spots the stationary phase, the rate of flow $\left(R_{f}\right.$ value) of the more strongly adsorbed substances will be the more retarded. The result is that the substances spread out along the plate depending on the relative affinities for the solvent and the layer. Substances that are not adsorbed at all will move directly with the solvent flow. Filield and Kearly ${ }^{23}$ described the rate of flow as:

$$
\begin{aligned}
& \text { Rf value } \\
& =\frac{\text { distance travelled by the center of solvent spot }}{\text { distance travelled by the front of mobile phase }}
\end{aligned}
$$

Under suitable conditions, the resulting different rates of flow can bring about complete separation of substances. The rate of flow $\left(R_{f}\right.$ value) is dependent on three factors: the activity of the layer, the saturation of the chamber, the uniform thickness of the layer. ${ }^{19}$

4. Experimental animals: Twenty two pregnant female albino rats, selected as explained below, were obtained from the experimental animal unit, University of Tripoli, Libya. Animals were clinically healthy, weighing 180$250 \mathrm{~g}$. All animals were housed in stainless steel cages with hard wood chips as bedding. Animals were maintained on a balanced diet composed of barley, milk and green fodder, with water ad libitum throughout the experimental period.

\section{Teratological study}

5.1. Determination of zero day of pregnancy: Female albino rats were monitored for estrus by taking daily vaginal smears for detecting cornified cells microscopically. The female that was proved to be in estrus was paired with a mature male in a separate cage. Sperm positive smear was taken as an indication of the zero day of pregnancy. ${ }^{24}$

5.2. Dosing and time of administration: The twenty two proved pregnant female albino rats were randomly divided into two groups. The first group (12 animals) was treated with $40.6 \mathrm{mg} / \mathrm{kg}$.b.wt of the plant extract on the $7^{\text {th }}$ day of gestation ${ }^{25,26}$ while the second group (10 animals) was kept as a control without treatment. The above mentioned dose is equivalent to $1 / 4$ of the $\mathrm{LD}_{50}$ of the extract which was calculated as $162.4 \mathrm{mg} / \mathrm{kg} . \mathrm{b} . \mathrm{wt}$ according to the method described by Behrens \& Karber. $^{27}$

5.3. Implantation sites: On the $20^{\text {th }}$ day of pregnancy, the treated as well as control dams were sacrificed. The uterus was exposed by necropsy and photographed externally to observe the resorption sites. The uterine horns were examined with a magnifying lens for tracing 
the implantation sites that appeared as black spot after being wet with $10 \%$ ammonium sulphide for 20 minutes. $^{28}$ The total number of the foeti in each animal was counted and alive and dead foeti were recognized and recorded (the survivability of the foeti was indicated by the rosy color, heart beating and active circulation). Foeti were also examined for sex determination, their weight and length of crown-rump were also recorded.

\subsection{Examination of the foetal skeleton for teratogenicity:} The picked out alive and dead foeti were eviscerated and kept in 95\% ethyl alcohol for 7 days, stained by Alizarin red as described by. ${ }^{29}$ The muscles of the foeti were digested in $2 \%$ potassium hydroxide for $6-8$ hours according to the size of foeti. The transparent foeti were immersed in Mallasch's solution with Alizarin red up to 24 hours for staining the skeleton. After that the foeti were passed into Mallasch's solution for 1 - 2 days for decoloration of stained muscles and then passed in graded concentration of glycerine-water solution $(50 \%, 70 \%$, $90 \% \& 100 \%$ ). All foeti were thoroughly examined according to the scheme advised by Cook and Fairweather ${ }^{30}$ as follows:

\section{Dam No.:}

Position of the fetus in the uterus:

Sex:

Skull:

Vertebral column:

Cervical vertebrae

Thoracic vertebrae

Lumber vertebrae

Sacral vertebrae

Coccygeal vertebrae

Fore Limb (left and right):

Humerus
Radius
Ulna
Meta carpals
Phalanges

Thorax and Pelvis:

Ribs

Sternaebrae

Pelvic girdle

Hind Limbs (left and right):

Femur

Tibia

Fibula

Patella

Meta tarsal

Phalanges

\section{RESULTS}

\section{Qualitative identification of the active ingredients:}

1.1. Phytochemical screening tests: Table 1 and Figure 2 show the reaction of the toxic active ingredients of the Citrullus colocynthis with different chemical reactions.

Table 1: The chemical tests for detection of the toxic active ingredients of the Citrullus colocynthis poisonous plant.

\begin{tabular}{|c|c|c|}
\hline & Test & Result \\
\hline \multirow{4}{*}{$\begin{array}{l}\text { Detection of } \\
\text { Glucosides } \\
\text { (carried out } \\
\text { on Lead } \\
\text { acetate } \\
\text { extract) }\end{array}$} & Molische's test & $\begin{array}{l}\text { Violet ring } \\
\text { between the two } \\
\text { reagents }\end{array}$ \\
\hline & Baljet's test & $\begin{array}{l}\text { Dark orange } \\
\text { precipitate }\end{array}$ \\
\hline & Fehling's test & $\begin{array}{l}\text { Reddish brown } \\
\text { precipitate }\end{array}$ \\
\hline & Benedict's test & $\begin{array}{l}\text { Reddish brown } \\
\text { precipitate }\end{array}$ \\
\hline \multirow{5}{*}{$\begin{array}{l}\text { Detection of } \\
\text { Alkaloids } \\
\text { (carried out } \\
\text { on macerated } \\
\text { extract) }\end{array}$} & Mayer's test & Turbidity \\
\hline & Wagner's test & Brown precipitate \\
\hline & $\begin{array}{l}\text { Dragendorff's } \\
\text { test }\end{array}$ & Orange precipitate \\
\hline & Hager's test & Yellow precipitate \\
\hline & Tannic acid test & White precipitate \\
\hline \multirow{2}{*}{$\begin{array}{l}\text { Detection of } \\
\text { saponins } \\
\text { (carried out } \\
\text { on macerated } \\
\text { extract) }\end{array}$} & $\begin{array}{l}\text { Mercurous } \\
\text { chloride test }\end{array}$ & White precipitate \\
\hline & $\begin{array}{l}\text { Ammoniated } \\
\text { silver nitrate } \\
\text { test }\end{array}$ & $\begin{array}{l}\text { Black precipitate } \\
\text { and mirror onto } \\
\text { the inner wall of } \\
\text { the test tube. }\end{array}$ \\
\hline \multirow{2}{*}{$\begin{array}{l}\text { Detection of } \\
\text { tannins } \\
\text { (carried out } \\
\text { on macerated } \\
\text { extract) }\end{array}$} & $\begin{array}{l}\text { Ferric chloride } \\
\text { test }\end{array}$ & $\begin{array}{l}\text { Dark bluish green } \\
\text { color }\end{array}$ \\
\hline & Tannic acid test & Dark color \\
\hline
\end{tabular}

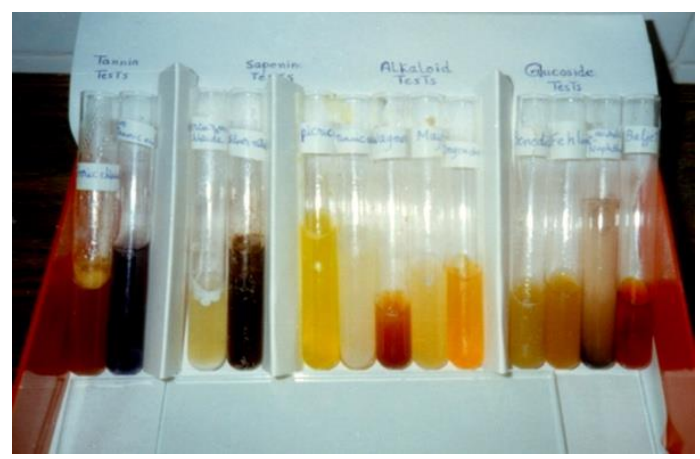

Figure 2: The chemical tests used for detection of the toxic active ingredients of the Citrullus colocynthis poisonous plant. 
1.2. Color reactions: the plant extract gives different color reactions with the used different chemical reagents as shown in Table 2 and Figure 3.

Table 2: The color reactions of Citrullus colocynthis with the different color reagents.

\begin{tabular}{|llll|}
\hline Reagent & $\begin{array}{l}\text { Color } \\
\text { developed }\end{array}$ & Reagent & $\begin{array}{l}\text { Color } \\
\text { developed }\end{array}$ \\
\hline Marquis & $\begin{array}{l}\text { Brown } \\
\text { precipitate }\end{array}$ & Libermann & $\begin{array}{l}\text { Yellow } \\
\text { precipitate }\end{array}$ \\
\hline Alizarin red & $\begin{array}{l}\text { Bloody } \\
\text { precipitate }\end{array}$ & $\begin{array}{l}\text { Mercurous } \\
\text { nitrate }\end{array}$ & No reaction \\
\hline $\begin{array}{l}\text { Bromocres } \\
\text { ol green }\end{array}$ & $\begin{array}{l}\text { Deep blue } \\
\text { precipitate }\end{array}$ & Beam's & No reaction \\
\hline Frohde & No reaction & $\begin{array}{l}\text { Ferric } \\
\text { chloride }\end{array}$ & $\begin{array}{l}\text { Oily } \\
\text { precipitate }\end{array}$ \\
\hline Vitali & $\begin{array}{l}\text { Yellow } \\
\text { precipitate }\end{array}$ & $\begin{array}{l}\text { Diluted } \\
\text { acetic acid }\end{array}$ & Transparent \\
\hline
\end{tabular}

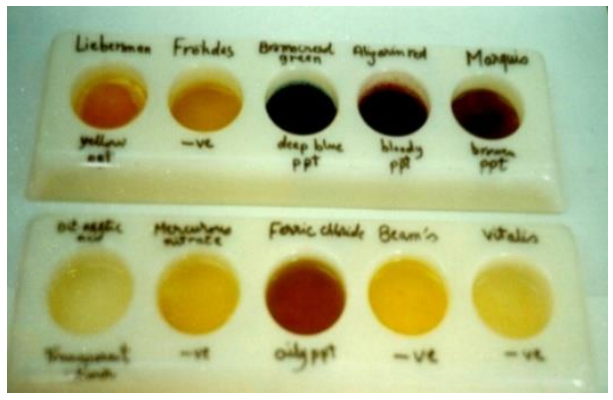

Figure 3: The different color reactions of Citrullus colocynthis extract with different reagents.

1.3. Thin layer chromatography: The visualization of colocynthis spots on silica gel was accomplished by spraying the compound with a spraying solution to help the location and characterization of the compound spots on chromatogram. The different adsorption rates of the reagent on the background substratum and that of the substance cited on spots offer a helpful mean of location purposes. The $R_{f}$ value of colocynthis using different eluents are shown in Table 3 and Figure 4.

Table 3: The $\mathbf{R}_{\mathrm{F}}$ value of Citrullus colocynthis on silica gel chromatoplates using mixture of some aromatic hydrocarbons.

\begin{tabular}{|llll|}
\hline Eluents & & & RF \\
Ratio (A:B) & Solvent B & Solvent A & value \\
\hline Chloroform & Methanol & $9: 1$ & 0.86 \\
\hline Benzen & Ethyl acetate & $7: 1$ & -ve \\
\hline Toluene & Ethyl acetate & $8: 2$ & -ve \\
\hline Sulphuric acid & Methanol & $3: 7$ & -ve \\
\hline Chloroform & Benzene & $1: 1$ & -ve \\
\hline Ethyl acetate & Benzene & $1: 1$ & -ve \\
\hline
\end{tabular}

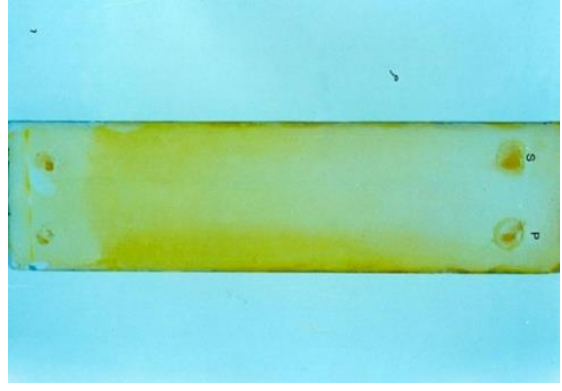

Figure 4: Flow rate $\left(R_{F}\right)$ value of the glucoside colocynthin on chromatogram plate.

\section{Teratological study}

2.1. Morphological examination: The total number of implantation sites in control and treated groups were 106 and 157, respectively; and the number and percentage of resorptions were highly significantly increased in the treated group compared to the control one. Fetal weight and the number of fetuses/dam were decreased compared to those in the control group as shown in Table 4 and Figures 5 \& 6

Table 4: The effect of Citrullus colocynthis extract on female rat reproduction.

\begin{tabular}{|llll|}
\hline & Item & $\begin{array}{l}\text { Non- } \\
\text { treated }\end{array}$ & Treated \\
\hline 1 & Dam bred & 20 & 20 \\
\hline 2 & Dam pregnant & 10 & 12 \\
\hline 3 & Litters examined & 90 & 91 \\
\hline 4 & Total implantation sites & 106 & 157 \\
\hline 5 & Litters with resorption & 16 & 66 \\
\hline 6 & Resorption \% & $15.09 \%$ & $42.04 \%$ \\
\hline 7 & Total fetal weight & $434.3 \mathrm{~g}$. & $353.9 \mathrm{~g}$. \\
\hline 8 & Average fetal weight & $4.82 \mathrm{~g}$. & $3.8 \mathrm{~g}$. \\
\hline 9 & No. of fetuses / dam & 9 & 7 \\
\hline
\end{tabular}

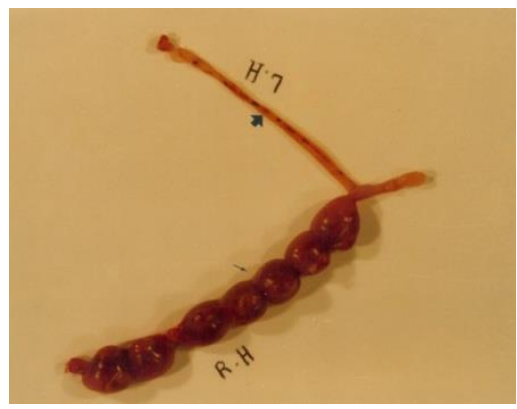

Figure 5: Uterus of a female rat treated with Citrullus colocynthis extract on the $7^{\text {th }}$ dayof gestation showing complete resorption of fetuses in the left horn (thick arrow) and dead fetuses in the right horn (thin arrow). 


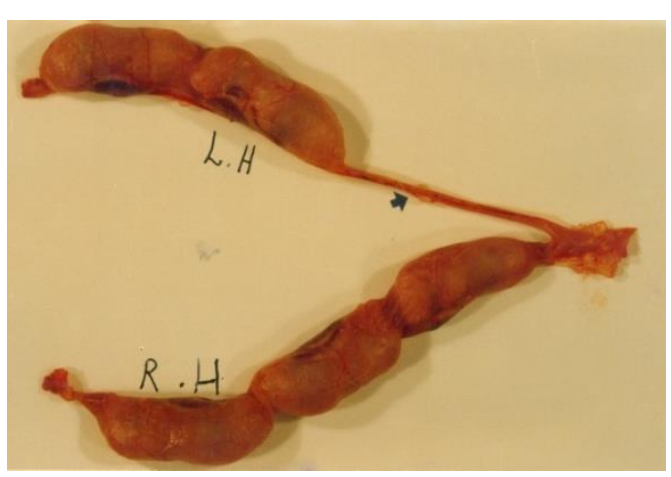

Figure 6: Uterus of a female rat treated with Citrullus colocynthis extract on the $7^{\text {th }}$ day of gestation showing resorption of some fetuses in the left horn (arrow).

2.2 Skeletal examination: Skeletal abnormalities in the fetuses of the treated dams were recorded in Table 5 and Figures $7 \& 8$. They were in the form of incomplete bipartite sternbrae, missing of sternbrae, metacarpal and carpal bones, metatarsal and tarsal bones, coccygeal vertebrae, rudimentary rib, incomplete ossification of parietal and interparietal bones of skull, incomplete ossification of occipital bone as well as incomplete union of vertebral column.

Table 5: The effect of Citrullus colocynthis on skeletal system of rat fetuses.

\begin{tabular}{|lllll|}
\hline \multirow{2}{*}{ Effect } & \multicolumn{3}{l}{ Non-Treated } & \\
\cline { 2 - 5 } & No. & $\%$ & No. & $\%$ \\
\hline Fetuses examined & 90 & 100 & 91 & 100 \\
\hline $\begin{array}{l}\text { Fetuses with } \\
\text { anomalies }\end{array}$ & 3 & 2.7 & 91 & 100 \\
\hline $\begin{array}{l}\text { Incomplete bipartite } \\
\text { sternbrae }\end{array}$ & - & - & 3 & 3.3 \\
\hline Missing sternbrae & - & - & 18 & 20 \\
\hline $\begin{array}{l}\text { Missing metacarpal } \\
\text { bones }\end{array}$ & 1 & 0.9 & 18 & 20 \\
\hline $\begin{array}{l}\text { Missing carpal } \\
\text { bones }\end{array}$ & 1 & 0.9 & 18 & 20 \\
\hline $\begin{array}{l}\text { Missing metatarsal } \\
\text { bones }\end{array}$ & 1 & 0.9 & 68 & 75.5 \\
\hline $\begin{array}{l}\text { Missing tarsal } \\
\text { bones }\end{array}$ & 1 & 0.9 & 61 & 67.7 \\
\hline $\begin{array}{l}\text { Missing coccygeal } \\
\text { bones }\end{array}$ & 2 & 1.8 & 75 & 83.3 \\
\hline Extra - rib & - & - & - & - \\
\hline Rudimentary rib & - & - & 14 & 15.5 \\
\hline Incomplete ossification of : & - & - & 72 & 80 \\
\hline Parietal bone & - & - & 72 & 80 \\
\hline Interparietal bone & 1 & 0.9 & 79 & 87.7 \\
\hline Occipital bone & $\begin{array}{l}\text { Incomplete union of } \\
\text { vertebral column }\end{array}$ & 1 & 82 & 91.1 \\
\hline
\end{tabular}

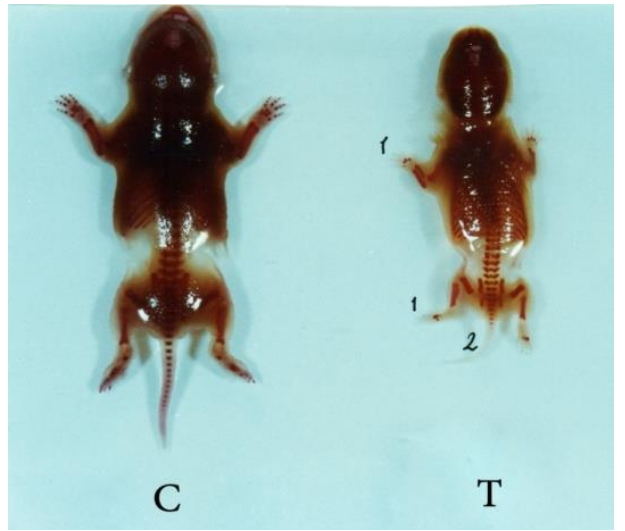

Figure 7: Skeletal abnormalities: (1) absence of digits in fore and hind limbs. (2) absence of coccygeal vertebrae in fetuses of rats treated with Citrullus colocynthis extract on the $7^{\text {th }}$ day of gestation; $(\mathrm{C}$ : Control; T: Treated).

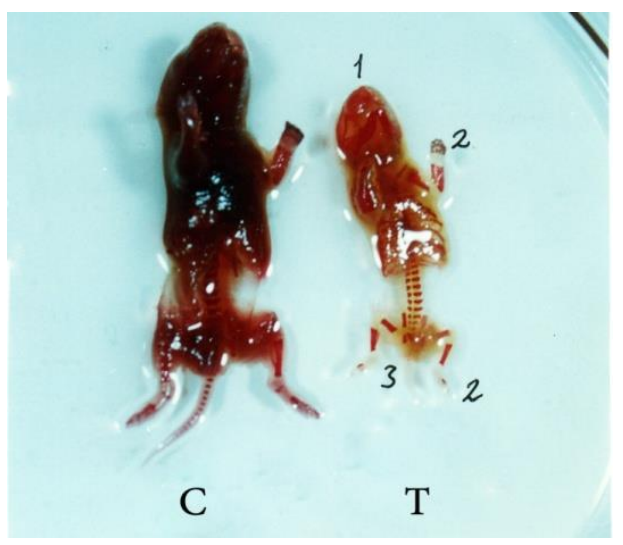

Figure 8: Skeletal abnormalities: (1) Incomplete ossification of cranial bone (2) Absence of digits in

fore and hind limbs (3) Absence of coccygeal vertebrae (4) Incomplete union of vertebral column in fetuses of rats treated with Citrullus colocynthis extract on the $7^{\text {th }}$ day of gestation; (C: Control; T: Treated).

\section{DISCUSSION}

The extraction of putative active principles from plant tissue was carried out by lead acetate for glucosides and by ordinary maceration method for alkaloid and saponins. The color tests for identification of the active ingredients of Citrullus colocynthis plant depend on variation of colors with the different compound and reagents used. ${ }^{31}$ Alizarin red gave bloody precipitate, Marquis gave brown precipitate, Liebermann's gave yellow precipitate and bromocresol green gave deep blue precipitate. As the color tests are not enough as a method of identification, a combination of thin layer chromatography and color reaction have been used to identify various compounds. ${ }^{32}$

Spraying of a chromatoplate using certain reagents produce different characteristic spots. These are used to 
determine the presence of a number of compounds. Isolation of the studied compounds could be done by thin layer chromatography which has the advantage of being able to indicate the presence of all the compounds. ${ }^{20,22}$ The solvent system chloroform: methanol (9:1) gave complete separation for all active ingredients.

With regard to the chemical tests, the glucoside colocynthin, alkaloids and saponins gave different identified colors and precipitates with the different reagents that were in agreement with those obtained by Rehm et al., ${ }^{17}$ and those of Clark ${ }^{31}$.

Appearance of structural and functional congenital defects have been observed in animals for centuries; ${ }^{33}$ later on, specific plants have been incriminated as etiologic agents. ${ }^{34,35}$ At this time, it is known that wide variety of plants, many of them common range plants, are capable of inducing congenital defects in offspring from pregnant individuals consuming the plant during some stages of gestation. In addition, the lack of any other available literature mentioning the congenital deformities in the offspring induced by Citrullus colocynthis led us to study these effects. The lack of information may be due to the fact that the appearance of these congenital deformities is delayed from the time of plant ingestion by the dam until the time of parturition. Our experimental work proved that Citrullus colocynthis can pass transplacentally, crossing barriers and inducing deformities in concept.

As it is known that the conceptus genotype determines susceptibility. ${ }^{25}$ Cows seem to be affected mainly by the lupines teratogen while sheep seem to be mainly affected by the veratum teratogen. ${ }^{36}$ Thus we can expect variation in susceptibility to Citrullus colocynthis among species, breed and strains of livestock. Variation in effect and incidence was found to be related to gestation period at which administration was given.

The previous fact is also of economic value in veterinary gynaecology and animal resources. Both malformation and growth-retarded fetuses were recorded in the same individuals at birth. No clinical signs were observed in dams giving malformed or retarded growth fetuses at the dose level given. This indicates that the embryo is more susceptible than the mother. Teratogenesis of Citullus colocynthis may be attributed to its effect on the replicating cells via alteration in replication, transcription, translation or cell division which accompanied by excessive necrosis ${ }^{37}$ as the embryo can tolerate substantial depression in DNA synthesis. ${ }^{38,39}$

\section{REFERENCES}

1. Radeleff R. Veterinary Toxicology. $2^{\text {nd }}$ Ed. Lea \&Febiger, USA. 1970.

2. Elgadi A, Hossain A. Poisonous plant of Lybia, National Council for Scientific Research, Tripoli, Lybia. The $1^{\text {st }}$ Ed.1986.
3. Bartik M, Piskac A. Veterinary Toxicology. Elsevier Scientific Publishing Company. Amsterdam, Oxford, New York.1980.

4. Watt JM, Breyer-Brand Wijk NG. Medicinal and poisonous plants of southern and eastern Africa $2^{\text {nd }}$ Ed., Livingstone, Edinburgh.1962.

5. Barri ME, Onsa TO, Elawad AA, Elsayed NY, Wasfi IA, Bari EM, Adam SE.Toxicity of five Sudanese plants to young ruminants. Journal of Comparative Pathology 1983;93: 559 - 575.

6. Kingsbury J.M. Poisonous Plants of the United States and Canada. Englewood Cliffs. New Jersey.1964.

7. Elawad AA, Abdel-Bari EM, Mahmoud OM, Adam SE. The effect of Citrulluscolocynthis on sheep. Veterinary and Human Toxicology 1984;26: 481485.

8. Bakhiet AO, Adam SE. An estimation of Citrullus colocynthis toxicity for chicks. Veterinary and Human Toxicology 1995;37: 356-358.

9. Dehghani F, Panjehshahin MR. The toxic effect of alcoholic extract of Citrullus colocynthis on rat liver. Iranian Journal of Pharmacology \& Therapeutics 2006;5: 117-119.

10. Dallak M, Bin-Jaliah I. Antioxidant activity of Citrullus colocynthis pulp extract in the RBC's of alloxan-induced diabetic rats. Pakistan Journal of Physiology 2010;6:1-5.

11. Gurudeeban S, Ramanathan T, Satyavani K, Dhinesh T. Antimicrobial effect of coastal medicinal plant Citrullus colocynthis against pathogenic microorganisms. African Journal of Pure and Applied Chemistry 2011;5: 119-122.

12. Talole BB, Baheti DG, More PA. Antihistaminic effect of Citrullus Colocynthis Linnschard leaves. Pharmacologyonline 2011;1: 468-472.

13. Azizi IG, Fard MH, Tahmasbipour S. The Effect of Aquatic and Alcoholic Extracts of Citrullus colocynthis on Growth of the Saprolegniaparasitica. World Journal of Fish and Marine Sciences 2012;4: 258-262.

14. Talabani NS, Tofiq DI. Citrullus colocynthis as a bioavailable source of $\beta$-sitosterol, antihyperlipidemic effect of oil in rabbits. International Journal of Medicinal Aromatic plants 2012;2: 536-539.

15. Reddy VP, Sudheshna G, Afsar SK, Saran SS, Kumar SN, Ram CR, Reddy KR. Evaluation of antiulcer activity of Citrullus colocynthis fruit against pylorus ligation induced ulcers in male wistar rats. International Journal of Pharmacy and Pharmaceutical Sciences 2012;4: 446-451.

16. Agarwal V, Sharma A, Upadhyay A, Singh G, Gupta R. Hypoglycemic effects of Citrullus colocynthis roots. Acta Poloniae Pharmaceutica (Drug Research) 2012;69: 75-79.

17. Rehm S, Enslin P, Meeuse D, Weesels J. Bitter principles of the cucurbitaceae. VII. The distribution of bitter principles in this plant family. J. Sci. Food Agric. 1957;8679-686. 
18. Trease GR. Textbook of Pharmacognosy Beulliere, Tindols and Cox, London, $8^{\text {th }}$ Ed., 1961; pp. 569.

19. Rentoul E, Smith H. Quoted from Glaister's Medical Jurisprudence and Toxicology 1973;227229.

20. Varley H. Chromatography. Partical Clinical Biochemistry $4^{\text {th }}$ Ed. William Heinemann, Medical Book. L. T. D. London.1969;pp. 41.

21. Sommaya H. Forensic Chemistry, Isolation and Identification of Poisons. Medico-Legal Department. Press-Cairo.1980.

22. Vagel A. Thin Layer Chromatography in Practicle Organic Chemistry. English Language Book Society. 1971;pp. 156.

23. Filield FW, Kearely D. Principle and practice of analysis chemistry, $1^{\text {st }}$ ed.; International textbook company. 1975.

24. Barcellona SP, Fanelli O, Campana A. Teratological study of etopri one in rat and rabbit. Toxicology 1977;2:87-94.

25. Wilson GR. Cytological effects of some antibiotics. J. Hered. 1965;41:226-231.

26. Fritz H, Hess R. Ossification of the rat and mouse skeleton in the perinatal period teratology 1970;3:331-338.

27. Behrens H, Karber S. Determination of LD50. Archives for Experimental Pathology and Pharmacy 1953;2:177-372.

28. Kopf R, Salewski SD. Arch. Expt. Pathol. Pharmacol. 1964;247 - 362. Cited by Cahem, RL. Chemoteratogenesis. Adv. Pharmacol. 1966;4:362334.

29. Staples R, Schnell V. Refinements in rapid clearing techniques in Kohalizarin red methods for foetal bone stain. Technology 1964;39:61.
30. Cook MJ, Fairweather FA. Pathogenic effects of Rubella virus on embryos and new born rats. Nature (London) 1968;217:38-40.

31. Clark E. Isolation and Identification of drugs 1968;84-120. London, The Pharmaceutical Press.

32. Clark E, Williams M. Garner's Veterinary Toxicology, $3^{\text {rd }}$ Ed. Williams \& Wilkins Co. Baltimore.1955.

33. Geoffroy Saint-Hilaire E. 1937; Cited by Majdy FA. Thesis M.Vet.Sci. Forensic Medicine and Toxicology, Zagazig University, Egypt.1990.

34. Binns W, Keeler RF, Balls LD. Clinical Toxicology 1972;5: 245.

35. Leipold HW, Ochme FW, Cook JE. Congenital athrogryposis associated with ingestion of jimson weed by pregnant sows. J Am Vet Med Assoc 1973;162:1059-1060.

36. Shupe JL, Keeler RF. Bovine Medicine and Surgery, $2^{\text {nd }}$ Ed. Sonita Barbara, California. American Vet. Publinic. 1980;1:439-492.

37. Mandel JD. A new clinical mutagen for bacteria, 1methyl-3-nitro soquanidine. Biochem. Res. Commun. 1960;30:575-577.

38. Ritter EJ. Altered biosynthesis in Handbook of Teratology. Springer US.1977;pp 99-116.

39. Kochhar DM, Penner JD, McDony JA. Limb developmental in mouse embryos. ii- Reduction defects, cytotoxicology and inhibition of DNA synthesis produced by cytosine arabinoside. Teratology 1978;18:71-92.

doi:10.5455/2319-2003.ijbcp20130818

Cite this article as: Elgerwi AA, Benzekri Z, El-

Magdoub A, El-Mahmoudy A. Qualitative identification of the active principles in Citrullus colocynthis and evaluation of its teratogenic effects in albino rats. Int J Basic Clin Pharmacol 2013;2:438-45. 